\title{
Influence of raw material properties on energy consumption during briquetting process
}

\author{
Tatiana Ivanova ${ }^{1}$, Bohumil Havrland ${ }^{1, *}$, Radek Novotny ${ }^{1}$, Alexandru Muntean ${ }^{1}$, and Petr Hutla ${ }^{2}$ \\ ${ }^{1}$ Czech University of Life Sciences Prague, Faculty of Tropical AgriSciences, Department of Sustainable Technologies, Kamýcká 129 , \\ 16521 Prague 6, Czech Republic \\ ${ }^{2}$ Research Institute of Agricultural Engineering, Drnovská 507, 16101 Prague 6, Czech Republic
}

\begin{abstract}
Biomass is doubtless a very significant source of renewable energy being worldwide abundant with high energy potential. This paper deals with assessment energy consumption at especially grinding and briquetting processes, which should result in essential economy of energy at solid biofuel production. Various types of raw materials were used at the experiment such as hemp (Cannabis sativa L.) biomass, two species of Miscanthus (Miscanthus sinensis, Miscanthus $x$ gigantheus) and apple wood biomass. These materials were dried, grinded and pressed by piston press having pressing chamber diameter of $65 \mathrm{~mm}$. Materials were grinded into three fractions $(4 \mathrm{~mm}, 8 \mathrm{~mm}$ and $12 \mathrm{~mm})$. Material throughput $\left(\mathrm{kg} \cdot \mathrm{h}^{-1}\right)$ and energy consumption $\left(\mathrm{kWh} . \mathrm{t}^{-1}\right)$ were registered. As to results: the highest throughput at both grinding cases as well as briquetting was found at apple wood biomass; however the energy consumption during briquetting of apple wood was relatively high. The worst results concerning throughput and energy consumption (especially at briquetting) were found at hemp biomass. Nevertheless, briquettes made of hemp had the best mechanical durability. Both Miscunthus species (herbaceous biomass) have very similar parameters and showed quite good relation between throughput and energy consumption at the used machines.
\end{abstract}

\section{Introduction}

In recent years, there has been a growing interest at the global level in the use of energy biomass [1]. Biomass is the third largest alternative energy source in the world, after coal and oil. Half of the world uses biomass energy as primary energy source [2]. Biomass can be divided into waste biomass, agricultural waste and deliberately grown biomass (energy crops). Biomass cycle can help to reduce $\mathrm{CO}_{2}$ concentrations [3] and it is the only renewable source that can be directly converted into solid, liquid or gas forms/biofuels [4].

Briquettes are produced by pressing equipment (piston press, screw press etc.). Briquetting increases energy density and significantly reduces volume of solid biofuel [5]. The big advantage is that briquetting process is pressing loose raw material into briquettes with a particular shape and reduces transportation and storage costs [1]. On the other hand, briquetting process is expensive; purchase price of briquetting lines and energy inputs are generally high [6].

There are several parameters which play an important role in briquetting process and affect the quality of briquettes as well as costs. Particle size of input material is very important for densification. According to [7] the optimum particle size is $6-8 \mathrm{~mm}$ with $10-20 \%$ powdery component (i.e. particles less than $4 \mathrm{~mm}$ ). Large particles (more than $12 \mathrm{~mm}$ ) are not suitable for briquette production, because final briquettes are not compacted. Input material has to contain smaller and also larger particles (random distribution of particle size is an optimum) as it contributes to better mechanical properties of produced briquettes [8]. According to [2] particle size and shape have also important effect on flow characteristics. The granular (preferably $6-8 \mathrm{~mm}$ in size) homogeneous materials which can flow easily in conveyors, bunkers and storage silos, are suitable for briquetting. Use of material with moisture content in a definite range (between 10-15\%) is very important for briquettes' quality and final product properties /both thermal and mechanical, too. For example, briquettes with high moisture content have worse combustion properties as high moisture leads to loss of heat and releasing large amount of water vapour, which can then cool and damage the heater [9]. Biomass drying process and its operation is expensive. Nevertheless, modern methods are improving drying technologies and efficiency of the dryers $[10,11]$

In order to produce good quality briquettes, briquetting press parameters (technological parameters) are also important [7]. As for example, compacting pressure influences strength of final briquettes. The quality of briquettes is increasing with increasing pressure in briquetting chamber [12]. Compacting

*Corresponding author: bohumilhavrland@gmail.com 
pressure depends on type of briquetting press. Compacting pressure can be higher, which is related to higher energy consumption. Compacting pressure can be lower, but the pressing temperature has to be higher. That means, when the temperature is higher, final briquettes will have similar quality as high compressed briquettes [13]. Also holding time is connected with compacting pressure. [14] made a research about effect of pressure and holding time by using hydraulic press with maximal pressure $138 \mathrm{MPa}$ and different holding times ranging between 0 to $60 \mathrm{sec}$. Experiment showed that holding pressure was more effected at lower pressure than at higher pressure. It follows from the study that compacting pressure is more important than holding time and the holding time at high pressure is negligible [14].

The present research paper is focused on analysis of energy consumption and material throughput, which were measured and calculated on examples of different biomass materials during both briquettes' production processes (grinding and briquetting) in order to evaluate the influence of raw material properties on above mentioned important processing characteristics. The following research hypotheses were formulated: 1) Hammer mill and piston press throughput and energy consumption differs depending on raw materials; 2) The particle size influences briquetting press throughput and energy consumption; 3) The grinding process is more energy intensive than briquetting process.

\section{Material and methods}

In total four different biomass materials were used for briquettes production: energy crops Mischanthus $x$ giganteus and Mischanthus sinensis - herbaceous species, industrial hemp (Cannabis sativa L.) - fibrous textile plant and apple wood biomass/apple tree trimming residues. All the materials were dried naturally.

\subsection{Biomass grinding and briquetting}

The grinding process was carried out using Hammer mill ŠV-15 (Stoza, Czech Republic) with energy input 15 $\mathrm{kW}$. The materials were crushed in three fractions (screening holes diameters: $4 \mathrm{~mm}, 8 \mathrm{~mm}$ and $12 \mathrm{~mm}$ ). Hammer mills widely used for material grinding as they are relatively cheap, easy to operate and produce wide range of particle sizes [15].

Briquetting was performed on hydraulic piston briquetting press Brikstar 30-12 (Briklis, Czech Republic) with working pressure $18 \mathrm{MPa}$, power intake $4.4 \mathrm{~kW}$, operation temperature $60^{\circ} \mathrm{C}$, control voltage 400 $\mathrm{V}$ Briklis and diameter of pressing chamber $65 \mathrm{~mm}$ [16]. Briquettes were produced without any additional binders.

\subsection{Determination of throughput and energy consumption}

Material throughput during grinding as well as briquetting process was determined from weight of used material and total grinding time, and recalculated per one hour.

In order to determine energy consumption (the energy spent on unit mass per time) during both processes, the measurements of electric energy consumption were conducted using Prowatt-3 with 16 A, $380 \mathrm{~V}$, Chauvin arnoux, France). Prowat-3 (see Figure 1) can measure three phases current and it is more accurate than normal electric meter. For each material and fraction the readings were taken every 10 minutes. The time is necessary for calculation, but also the mass of material is important. The energy consumption was then calculated for $60 \mathrm{~min}$ and energy consumption for one tonne of input material.

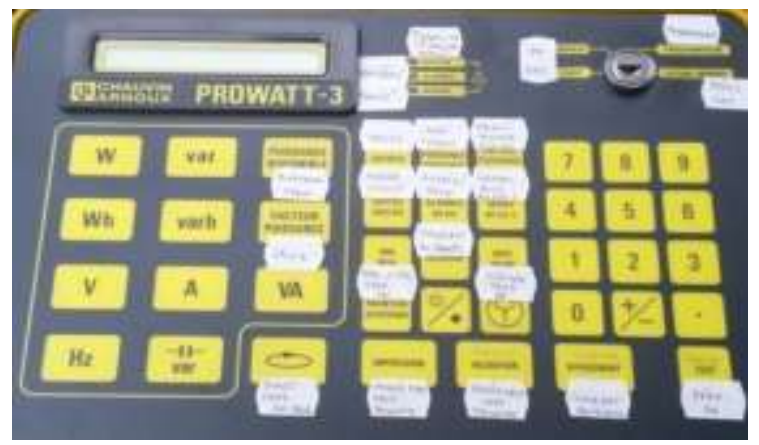

Fig. 1. Prowatt-3.

\subsection{Determination of biomass moisture content}

Determination of moisture content of biomass before briquetting process was conducted according to the applicable standard EN ISO 18134-2:2015-1: method of drying at a temperature of $105{ }^{\circ} \mathrm{C}$ in laboratory drier UFE 500 - MEMMERT. For calculation of moisture content the following equation was used:

$$
w=\frac{m_{w}-m_{d}}{m_{w}} \times 100, \%
$$

where: $w$ - moisture content $(\%), m_{w}-$ wet material weight $(\mathrm{g}), m_{d}-$ dry material weight $(\mathrm{g})$.

\subsection{Determination of mechanical durability of briquettes}

Mechanical durability determination of produced briquettes was done according to the standard EN ISO 17831-2:2015 in briquette durability drum of cylindrical shape and volume of 160 . Each sample portion of about $2 \mathrm{~kg}$ was rotated at $21 \pm 0.1$ revs. $\mathrm{min}^{-1}$ for 5 minutes. The mechanical durability was calculated by following equation:

$$
D U=\frac{m_{A}}{m_{E}} \times 100, \%
$$

where: $D U-$ mechanical durability $(\%), m_{A}-$ weight of input briquettes $(\mathrm{kg}), m_{E}$ - weight of output briquettes ( $\mathrm{kg})$. 


\section{Results and discussion}

\subsection{Evaluation of hammer mill throughput}

The results of material consumption of the hammer mill for each tested material and each fraction are presented at the Figure 2. From the Fig. 2 is evident that the material throughput varies (differs) by used material and there is significant difference between apple wood and other materials, especially hemp. It is visible that the apple wood had the highest (the best) throughput. From the result of apple wood is also clear that the fraction 12 $\mathrm{mm}$ has higher throughput than the others fractions, followed by $8 \mathrm{~mm}$ and then $4 \mathrm{~mm}$. Hammer mill throughput showed rising trend with increase of screen size during grinding of this wood material. Miscanthus $x$ gigantheus (149.65, 140.29 and $148.64 \mathrm{~kg} . \mathrm{h}^{-1}$ ) and Miscanthus sinensis $\left(129.48,136.00\right.$ and $\left.149.65 \mathrm{~kg} . \mathrm{h}^{-1}\right)$ have almost similar throughput. During the grinding of these straw materials were not found differences between fractions. Hemp have different (very low) values $\left(80.40,41.50\right.$ and $\left.51.71 \mathrm{~kg} . \mathrm{h}^{-1}\right)$ comparing to other materials. During the measurements were observed complications with grinding of hemp due to the rolling of hemp fibres on hammers of the grinding machine.

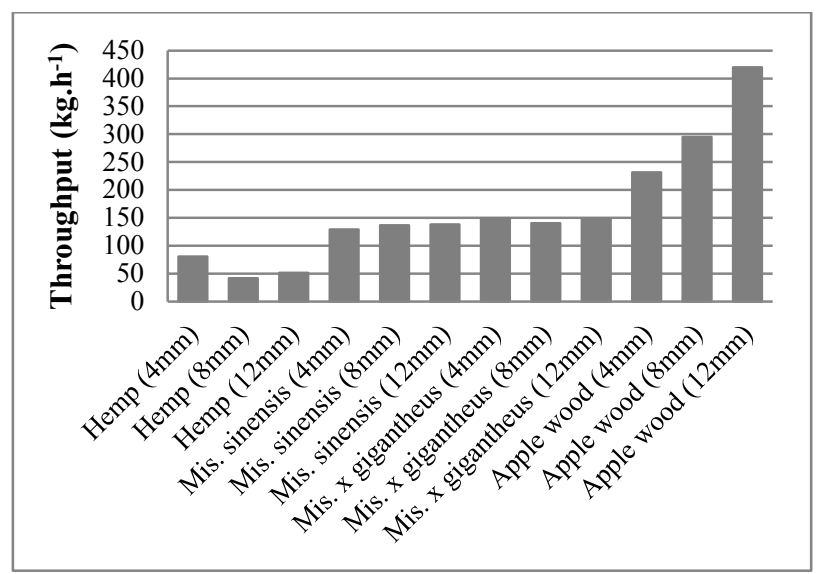

Fig. 2. Hammer mill throughput.

[17] determined material throughput for switchgrass, wheat straw and corn stover. The throughput was similar for each material and the value was $150 \mathrm{~kg} \cdot \mathrm{h}^{-1}$. [18] used chopping machine in the research and corn stalk as tested material. The particle size of the corn stalk from the chopping machine was $4 \mathrm{~mm}$. The authors has recorded that the chopping capacity of the machine ranges from 300 to $500 \mathrm{~kg} \cdot \mathrm{t}^{-1}$. It could be said that corn stalk has structure similar to Miscantus x gigantheus, however, in the present research Miscanthus $x$ gigantheus with fraction $4 \mathrm{~mm}$ had throughput for hammer mill at least two times smaller.

\subsection{Evaluation of hammer mill energy consumption}

Figure 3 illustrates the average energy consumption for grinding of selected biomass using the hammer mill with three different screen sizes. Energy consumption to reduce hemp to particle sizes 4,8 and $12 \mathrm{~mm}$ was 65.97 , $117.47,66.85 \mathrm{kWh} . \mathrm{t}^{-1}$, respectively. Hemp had medium and non-trended energy consumption in comparison with other materials. From the Fig. 3 is evident that the Miscunthus sinensis and Miscunthus $x$ gigantheus had the lowest energy consumption, and apple wood had the highest energy consumption (141.25, 135.29 and 129.52 $\left.\mathrm{kWh} \cdot \mathrm{t}^{-1}\right)$, that can be explained as wood is hard material for grinding.

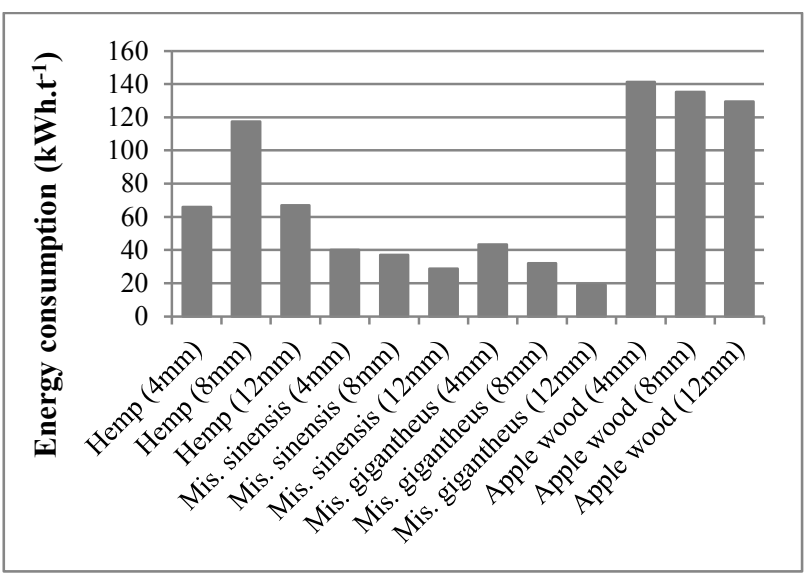

Fig. 3. Hammer mill energy consumption.

Fig. 3 also shows differences between fractions. In case of both Miscanthus and apple wood energy consumption was rising with decrease of screen size, i.e. fractions $12 \mathrm{~mm}$ and $8 \mathrm{~mm}$ had less energy consumption than fraction $4 \mathrm{~mm}$. [19] measured energy consumption of hammer mill using switchgrass, which has stalk structure more similar to Miscanthus sinensis, and screen sizes $0.8,1.6$ and $3.2 \mathrm{~mm}$. The results confirmed the difference between fractions. The smallest fraction 0.8 $\mathrm{mm}$ had the highest energy consumption of $62.55 \mathrm{kWh} . \mathrm{t}^{-}$ ${ }^{1}$, followed by fraction $1.6 \mathrm{~mm}-51.76 \mathrm{kWh} \cdot \mathrm{t}^{-1}$ and 3.2 $\mathrm{mm}$ - $23.84 \mathrm{kWh} \cdot \mathrm{t}^{-1}$. The energy consumption of hammer mill was also comparable with the work of [20], where the same relation between screen size and energy consumption was found. In contrast, [18] has measured energy consumption of chopping machine using corn stalk and screen size $4 \mathrm{~mm}$, which was equal to 20 $\mathrm{kWh} . \mathrm{t}^{-1}$. The hammer mill showed higher energy consumption and only Miscanthus $x$ gigantheus (fraction $12 \mathrm{~mm}$ ) has energy consumption $19.08 \mathrm{kWh} . \mathrm{h}^{-1}$. [19] has also reported a relation between energy consumption and moisture content of input material, i.e. the higher the moisture, the higher the energy consumption is.

\subsection{Evaluation of moisture content of tasted materials}

The results of material moisture contents after grinding before briquetting process are presented on the Figure 4 . It is visual that the moisture content is not more than $15 \%$. This value is a maximum border for briquettes production by Brikstar press 30-12 [16]. According to [16] the lowest moisture content of input material is $8 \%$, but in the present research the materials with even lower moisture contents were tested for densification as well. 


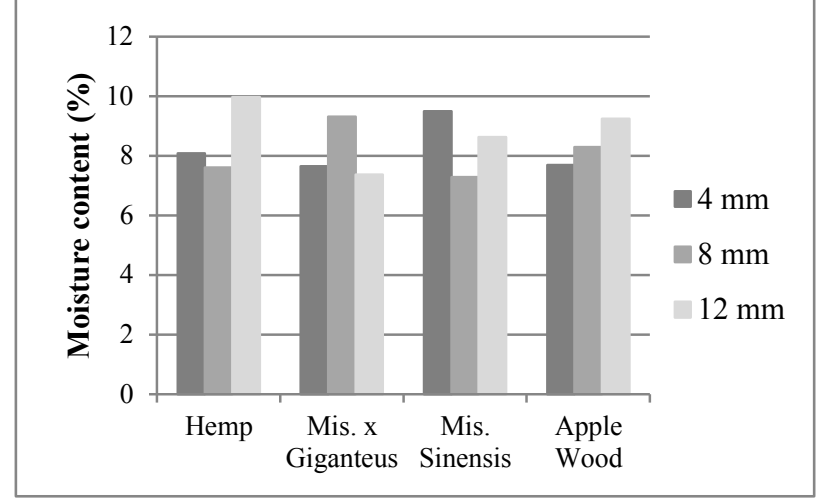

Fig. 4. Biomass material moisture content.

\subsection{Evaluation of briquetting press throughput}

The material throughput during briquetting is evident from the Figure 5 and it shows that throughput depends on particle size. The same dependence was mentioned by [2]. Particle size $4 \mathrm{~mm}$ had higher material throughput than other fractions within each tested material, so material with smaller particle size was easily pressed.

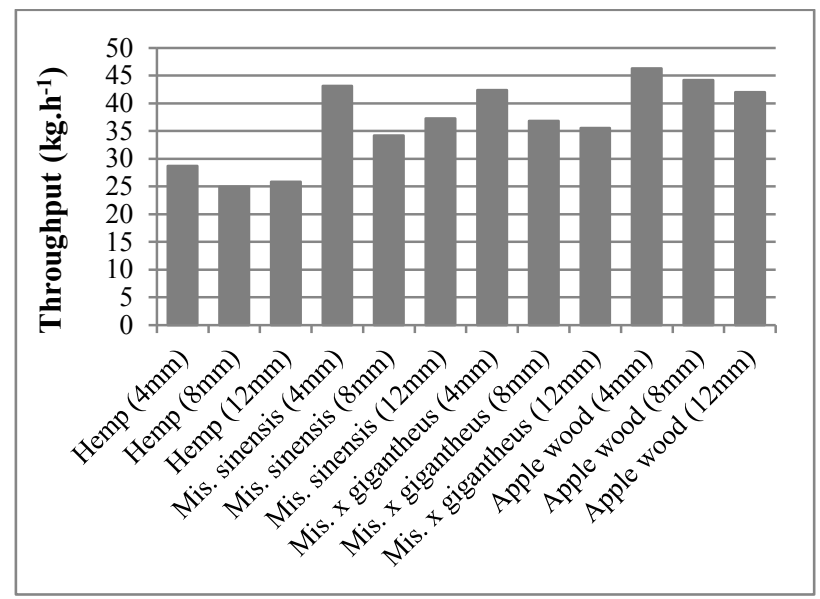

Fig. 5. Briquetting press throughput.

The throughput for fractions $4 \mathrm{~mm}$ was: hemp $28.71 \mathrm{~kg} \cdot \mathrm{h}^{-1}$, Miscanthus sinensis - $43.16 \mathrm{~kg} . \mathrm{h}^{-1}$, Miscanthus $x$ gigantheus $-42.40 \mathrm{~kg} \cdot \mathrm{h}^{-1}$ and apple wood $46.30 \mathrm{~kg} . \mathrm{h}^{-1}$. Both Miscanthus species showed overall similar throughput during briquetting. Briquetting throughput for apple wood was in general the highest in comparison with other materials as well as it corresponds to the best throughput of wood biomass during grinding, however, the difference between throughput of wood and Miscanthus materials within briquetting is not such significant like during the grinding. As in case of all the materials the best briquetting throughput showed smaller fraction $4 \mathrm{~mm}$, but in case of hammer mill throughput it was different (opposite) and the fraction $12 \mathrm{~mm}$ had mainly highest throughput there. The lowest throughput was again detected for hemp (Fig. 5).

According [16] the piston press Brikstar 30-12 has material throughput $20 \mathrm{~kg} \cdot \mathrm{h}^{-1}$ to $40 \mathrm{~kg} \cdot \mathrm{h}^{-1}$. From the Fig. 5 is evident that the measured throughputs are basically in the range, nevertheless all fractions of apple wood showed higher values $\left(46.30 \mathrm{~kg} . \mathrm{h}^{-1}, 44.20 \mathrm{~kg} \cdot \mathrm{h}^{-1}\right.$ and
$42.00 \mathrm{~kg} . \mathrm{h}^{-1}$ ). From the Fig. 4 and Fig. 5 is obvious that hemp with moisture content of $7.60 \%, 8.08 \%$ and $9.97 \%$ has the lowest briquetting throughput while apple wood with moisture content of $7.69 \%$ or $8.29 \%$ has higher throughput, so impact of moisture is now visible. It seems that throughput depends on material type and particle size. Additionally, it should be mentioned that hammer mill throughput was in general notably higher than throughput of briquetting.

\subsection{Evaluation of briquetting press energy consumption}

The energy required for compaction of materials into briquettes at different particle sizes is shown in the Figure 6 . The energy consumption was in the range of $43.91 \mathrm{kWh} \cdot \mathrm{t}^{-1}$ to $115.24 \mathrm{kWh} \cdot \mathrm{t}^{-1}$. From the energy consumption is clear which material is more suitable for briquettes production. The highest energy consumption had hemp fractions $4 \mathrm{~mm}$ and $8 \mathrm{~mm}\left(115.24 \mathrm{kWh} \cdot \mathrm{t}^{-1}\right.$ and $\left.107 \mathrm{kWh} \cdot \mathrm{t}^{-1}\right)$.

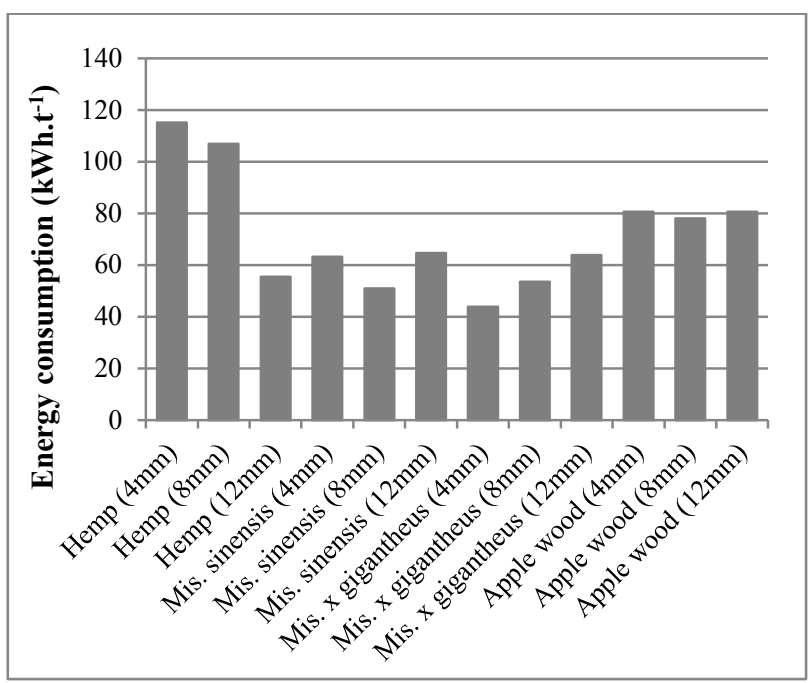

Fig. 6. Briquetting press energy consumption.

Positive results, i.e. relatively low consumption and generally the best values comparing to apple wood and hemp, had both Miscanthus for all fractions. Energy consumption for these materials was in the range of $43.91 \mathrm{kWh} . \mathrm{t}^{-1}$ to $64.67 \mathrm{kWh} \cdot \mathrm{t}^{-1}$ and it was visible that briquetting process is more energy intensive than grinding process in general. Apple wood with energy consumption $4 \mathrm{~mm}-80.65 \mathrm{kWh} . \mathrm{t}^{-1}, 8 \mathrm{~mm}-78.00 \mathrm{kWh} . \mathrm{t}^{-1}$ and $12 \mathrm{~mm}-80.67 \mathrm{kWh} \cdot \mathrm{t}^{-1}$ is characterized by higher energy consumption then Miscanthus, but lower then hemp (see Fig. 6). [21] published that the specific energy consumption of briquetting press is in the range of 44 $\mathrm{kW} \cdot \mathrm{t}^{-1}$ to $70 \mathrm{~kW} \cdot \mathrm{t}^{-1}$. The energy consumption of Miscanthus biomass is in this range.

\subsection{Evaluation of mechanical durability of produced briquettes}

From the point of view of the mechanical durability (Figure 7) the briquettes from apple wood showed just average values (and even the lowest durability), while 
hemp briquettes showed the best one. In research of [22] sawdust and shavings (woody materials) had also mechanical durability of $91 \%$ (sawdust) and $92 \%$ (shavings).

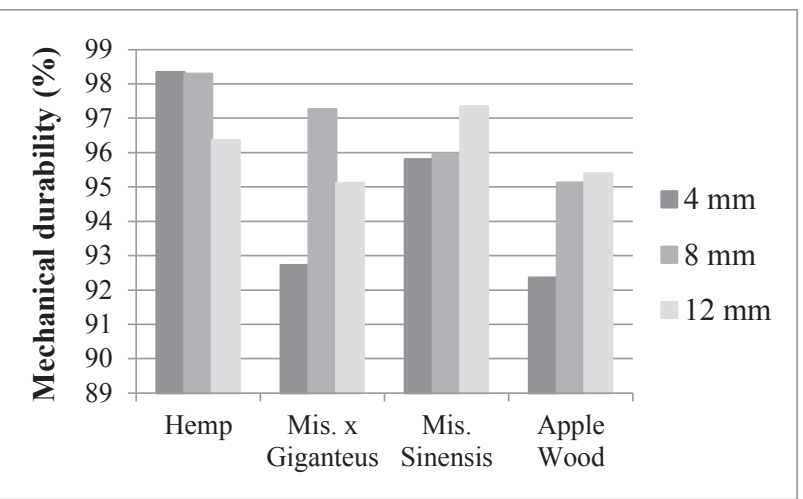

Fig. 7. Mechanical durability of produced briquettes.

The interesting fact is in contrast between briquettes made from hemp and other materials; it can be probably explained by hemp biomass structure - by better connection of fibrous particles.

[23] shows relevance between briquetting temperature and briquettes density. It was stated that the briquettes density grows proportionally to increasing temperature; when the temperature is higher it is possible to use lower pressure for briquetting. [2] has also conducted a research about temperature influences and has found that the briquettes made with temperature more than $90^{\circ} \mathrm{C}$ have higher density then other briquettes made at room temperature. According to [12] temperature at the pressing process is significant for lignin excretion from cellular structure. When the temperature rises to $80^{\circ} \mathrm{C}$ lignin is secreted from the structure of the cellulose skeleton and intercellular space [5]. [24] indicated that lignin present in the biomass is fluidized and acts as glue when the temperature increases. The temperatures between $85-105^{\circ} \mathrm{C}$ would result in much stronger briquettes. Relatively low operational temperature of briquetting press Brikstar 3012 used in the present research may explain the generally lower mechanical properties of produced briquettes.

\subsection{Summarization of grinding and briquetting processes of used materials}

The total throughput for both processes grinding and briquetting as well as the total energy consumption during grinding plus briquetting are presented in the Figure 8. From the results of throughput is evident that the most suitable material for processing is apple wood, while hemp is the less suitable. The total throughputs corresponding to different fractions of apple wood were: $4 \mathrm{~mm}-277.80 \mathrm{~kg} \cdot \mathrm{h}^{-1}, 8 \mathrm{~mm}-339.87 \mathrm{~kg} \cdot \mathrm{h}^{-1}$ and $12 \mathrm{~mm}$ $462.00 \mathrm{~kg} \cdot \mathrm{h}^{-1}$, and for hemp: $4 \mathrm{~mm}-109.11 \mathrm{~kg} \cdot \mathrm{h}^{-1}, 8 \mathrm{~mm}$ - $66.40 \mathrm{~kg} \cdot \mathrm{h}^{-1}$ and $8 \mathrm{~mm}$ - $77.57 \mathrm{~kg} \cdot \mathrm{h}^{-1}$. Miscanthus sinensis and Miscanthus $x$ gigantheus had similar material throughput, which ranged from $171.00 \mathrm{~kg} \cdot \mathrm{h}^{-1}$ to $192.05 \mathrm{~kg} \cdot \mathrm{h}^{-1}$.

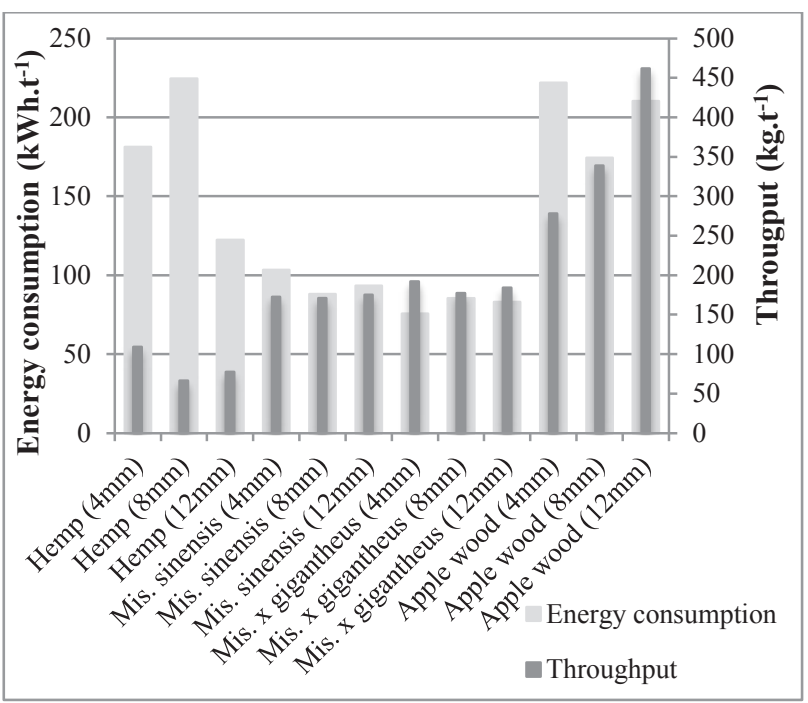

Fig. 8. Total throughput and energy consumption of the whole production process.

Research revealed that the apple wood had similar (high) energy consumption as hemp, and the total energy required for briquettes production from Miscanthus biomass was the lowest. Taking into account all the experimental results, it could be stated that wood material is applicable for briquettes' production, but processing of bigger screen sizes is recommended, as well as herbaceous Miscanthus biomass showed relatively good relation between throughput and consumed energy.

\section{Conclusions}

The research confirmed the first hypothesis. During the evaluation of throughput of different materials, in both processes (grinding and briquetting) the best results showed apple wood, very similar throughput was between two types of Miscanthus (herbaceous biomass) a significantly worse throughput had the hemp (fibrous material). According to the used material, energy consumption during grinding and briquetting can also differ. The lowest consumption had the herbaceous biomass. The highest energy consumption was recorded during grinding of hard wood and during briquetting of hemp.

Research partly confirmed the second hypothesis. During the evaluation of the influence of fractions on throughput, the best throughput during briquetting had all materials with the smallest fraction of $4 \mathrm{~mm}$. During grinding process the significant difference between fractions was visible only in case of wood, where on contrast the bigger fraction(s) caused better throughput. From the energy consumption point of view, the finer the fraction was during grinding, the higher was the energy consumption - as confirmed form wood and both Miscanthus species. During briquetting any typical trend was not visible.

Research partly confirmed the third hypothesis. In case of wood the energy consumption during grinding was significantly higher than during briquetting. On the contrary, during briquetting of two types of Miscanthus, 
the energy consumption was higher (almost double). Average energy consumption during grinding and briquetting of hemp was similar, slightly higher during briquetting.

The study was supported by the Internal Grant Agency of the Faculty of Tropical AgriSciences, Czech University of Life Sciences Prague, research grant number 20165012 and 20175011 as well as by Internal project in the framework of Institutional support of RIAE development (decision number RO0614) - project title "New technologies of targeted biomass processing into raw materials and advanced biofuels".

\section{References}

1. Z. Wang, T. Lei, M. Yang, Z. Li, T. Qi, X. Xin, X. Yan, Applied Energy 192, 83-94 (2017)

2. L. Chen, L. Xing, L. Han, Renew Sust Energ Rev 13, 224-232 (2009)

3. B. Havrland, T. Ivanova, B. Lapczynska-Kordon, M. Kolarikova, $12^{\text {th }}$ International scientific conference Engineering for rural development, Jelgava, 541-544 (2013)

4. H. Kambo H., A. Dutta, Applied Energy 135, 182191 (2014)

5. A. Muntean, T. Ivanova, B. Havrland, V. Pobedinsky, $11^{\text {th }}$ International scientific conference Engineering for rural development, Jelgava, 496499 (2012)

6. P. Král, J. Hrázný, Utilization of wood and other lignocellulosic wastes (Mendel University, Brno, 1999)

7. D. Grover, K. Mishra, Biomass briquetting: technology and practices (FAO, 1996)

8. J. Oladeji, C. Enweremadu, International Journal of Energy Engineering 2, 22-27 (2012)

9. P. Jevič, P. Hutla, Z. Šedivá, Sustainable production and quality control of solid fuels based on agricultural bioproducts (Research Institute of Agricultural Engineering, Prague, 2008)

10. B. Havrland, P. Hutla, D. Adamovský, Agricultura tropica et subtropica 43, 19-28 (2010)

11. T. Ivanova, Research of energy plants processing to solid biofuels (Czech University of Life Sciences Prague, Prague, 2012)

12. P. Križan, L. Šooš, M. Matúš, M. Svátek, D. Vukelic, $9^{\text {th }}$ International Conference APLIMAT, Bratislava, 124-136 (2009)

13. J. Kers, P. Kulu, A. Aruniit, V. Laurmaa, P. Križan, L. Šooš, Ü. Kask Estonian Journal of Engineering 16, 07-316 (2010)

14. Y. Li, H. Liu, Biomass Bioenergy 19, 177-186 (2000)

15. P. Lopo, Feed Management 53, 23-26 (2002)

16. Briklis, Available http://www.briklis.cz/briketovaci-lis/cs/\#producttabs $=$ obecne_informace (2011)
17. V.S. Bitra, A.R. Womac, N. Chevanan, P.I. Miu, C. Igathinathane, S. Sokhansanj, D.R. Smith, Powder Technol 193, 32-45 (2009)

18. J. Hu, T. Lei, Z. Wang, X. Yan, X. Shi, Z. Li, Energy 61, 557-566 (2014)

19. S. Mani, L.G. Tabil, S. Sokhansanj, Biomass Bioenergy 27, 339-352 (2001)

20. L. Cadoche, G. López, Biological Wastes 30, 153157 (1989)

21. T. Ivanova, A. Muntean, B. Havrland, V. Pobedinsky, Agronomy Research 11, 47-52 (2013)

22. M. Brožek, A. Nováková, M. Kolářová, Research in Agricultural Engineering 58, 30-35 (2012)

23. A. Demirbasa, Physical properties of briquettes from waste paper and wheat straw mixtures, Energ Convers and Manage 40, 437-445 (1999)

24. A. Tripathi, P. Iyer, T. Kandpal, Biomass Bioenergy 14, 479-488 (1998) 